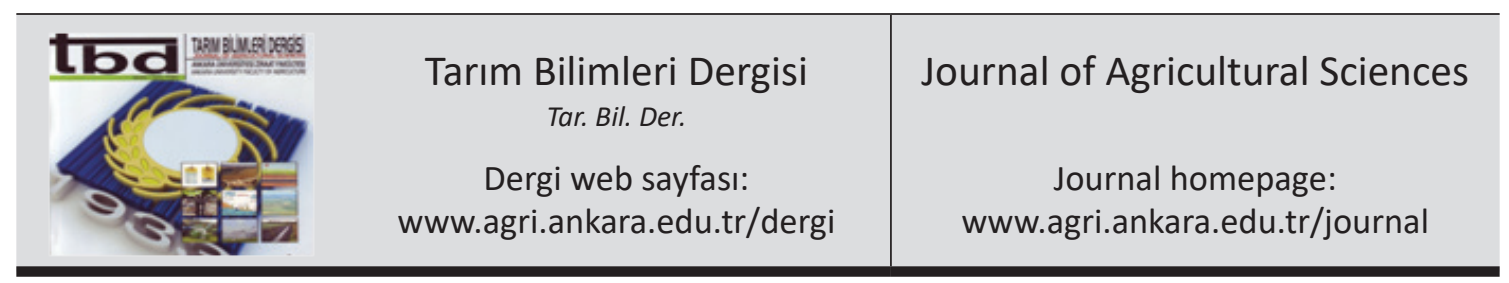

\title{
Biochemical Characterization of Fig (Ficus carica L.) Seeds
}

\author{
Emine NAKİLCİOĞLU TAŞ ${ }^{\mathrm{a}}$ \\ ${ }^{a}$ Ege University, Faculty of Engineering, Food Engineering Department, 35100, Bornova, Izmir, TURKEY
}

\section{ARTICLE INFO}

Research Article

DOI: 10.15832 /ankutbd.398268

Corresponding Author: Emine NAKİLCİĞLU TAȘ, E-mail: emine.nakilcioglu@ege.edu.tr, Tel: +90 (232) 31130

07 Received: 24 February 2018, Received in Revised Form: 13 July 2018, Accepted: 15 August 2018

\begin{abstract}
Fig fruit has been a typical component of the health-promoting Mediterranean diet since centuries. One of the fig fruit's parts responsible for health effects is fig seeds that do not come to mind. Firstly, the proximate compositions of Sarilop fig seed cultivars were determined in this study. It was seen that the fig seeds were rich in oil and carbohydrate contents. Then, the mineral contents of fig seeds were analyzed by UV-vis spectrophotometer and an atomic absorption spectrometer. The major minerals in fig seeds were found as $\mathrm{Ca}, \mathrm{K}$ and P. Moreover, the fatty acid compositions of the seeds were evaluated by gas chromatography. The fig seed oil had greater amount of the unsaturated fatty acids than saturated fatty acids. The chemical compositions of fig seeds are presented for the first time in this study.
\end{abstract}

Keywords: Fatty acids; Ficus carica L.; Fig seeds; Mineral content

(C) Ankara Üniversitesi Ziraat Fakültesi

\section{Introduction}

Fig is a fruit, which belongs to the Moraceae family and has more than 750 varieties (Guvenc et al 2009). Among them, Ficus carica L. is an edible fruit species. Figs can be consumed as raw, dried, canned, or in other preserved forms (Mawa et al 2013). Commercial producers of figs are in countries such as Turkey, Egypt, Morocco, Spain, Greece, California, Italy, Brazil, and other countries with hot dry summers and mild winters. Turkey leads in the fig production with $30 \%$ of the world fig production (Nakilcioğlu \& Hişil 2013; Mehta et al 2014). It is an important constituent of the Mediterranean diet due to its energy, minerals, dietary fiber, amino acids and antioxidants compounds such as phenolic compounds and vitamins contents (Oliveira et al 2010; Bucić-Kojić et al 2011; Amessis-Ouchemoukh et al 2017). The fruits, root and leaves of fig trees are known for quite a number of therapeutic properties such as their use in traditional medicine for the treatment of cardiovascular, respiratory (sore throats, coughs, and bronchial problems) and gastrointestinal (colic, indigestion, loss of appetite, and diarrhea) disorders and as anti-inflammatory and antispasmodic remedy (Mawa et al 2013; Amessis-Ouchemoukh et al 2017).

One of the attractive parts of whole figs effecting both their nutritional values and health effects is their seeds. The interior portion of fig is a white, inner ring containing a seed mass bound with jelly-like flesh (Badgujar et al 2014). Fig seeds vary greatly in size such as large, medium, small, or minute and their number is from 30 to 1600 per fruit (Lansky et al 2008; Badgujar et al 2014). For example, the 
mean of seed number per a fruit is 420 and 1000 seed weights are $1.28 \mathrm{~g}$ for 'Sarilop' fig cultivars (Çalişkan et al 2012). In a fig, there are numerous edible seeds and they are usually hollow, unless pollinated. The characteristic nutty taste of dried figs is also provided from their seeds. Nowadays, the fig seeds may be used as edible oil and lubricant source (Badgujar et al 2014).

Fig is a fruit that is consumed together with many seeds found in its jelly-like flesh, with or without its peel. For this reason, it is considered that the fig seeds contribute considerably to the nutritional composition of fig. The aim of the present study is to determine the chemical properties and nutritional composition of fig seeds obtained from different fig cultivars produced in Turkey. This study may contribute to improvement and enhancement of the information contained in the literature about chemical and nutritional properties of figs. Moreover, this study is very important in terms of the fact that the chemical composition of fig seed is the first to be enlightened.

\section{Material and Methods}

\subsection{Materials}

\subsubsection{Samples}

In this study, Sarilop fresh figs grown in three different locations (Incirliova, Germencik, Nazilli) were bought from local markets in Turkey. They were chopped into a water bath and their seeds were extracted. After the extracted seeds were washed several times with water, they were left to dry at room temperature for one week (Engin et al 2011). The obtained fig seeds were stored at $4{ }^{\circ} \mathrm{C}$ until analysis.

\subsection{Methods}

\subsubsection{Proximate composition analyses}

The chemical compositions (moisture, ash, oil and protein) of fig seeds were determined by the official methods reported by the Association of Official Analytical Chemists (AOAC 2000). The carbohydrate contents of the samples were calculated by subtracting their moisture, ash, protein and fat contents from 100. The proximate compositions were expressed as a percentage.

\subsubsection{Mineral analyses}

$2.5 \mathrm{~g}$ of the fig seeds were weighed in the porcelain crucible and incinerated at $550 \mathrm{C}$ in a muffle oven during 8-10 h. The ashes that are white-grayish in color were slightly moistened and dissolved with three parts of $2 \mathrm{~mL}$ of $6 \mathrm{~N}$ hydrochloric acid. Then, they were filtered into a $25 \mathrm{~mL}$ volumetric flask. After the filter was cleaned three times with 3 $\mathrm{mL}$ of deionized water that was also added to the volumetric flask, it was filled with deionized water until level (López et al 2008). Mineral analyses were applied by using the obtained solution. The $\mathrm{Mg}, \mathrm{Zn}, \mathrm{Fe}, \mathrm{Cu}, \mathrm{Na}, \mathrm{K}, \mathrm{Ca}$ and $\mathrm{Mn}$ measurements were performed with a Model contrAA 700 highresolution continuum source atomic absorption spectrometer (Analytik Jena, Jena, Germany), with a flame atomize. The amounts of $\mathrm{P}$ in the samples were determined by UV-vis spectrophotometer (Optizen Pop, Mecasys Co., Ltd., Korea) according to AOAC method 965.17-1966 (AOAC 1996). The mineral contents were expressed as mg of mineral per kg for samples.

\subsubsection{Fatty acids analysis}

The oil of fig seeds was extracted at room temperature with n-hexane, and then, was methylated directly according to IUPAC method 2.201 (Paquot \& Hautfenne 1987). The compositional analysis of fatty acid methyl esters was performed by using a gas chromatograph (Agilent 7820A) equipped with a flame ionization detector and a capillary column (Agilent DB-23, $30 \mathrm{~m} \times 0.25 \mathrm{~mm}$ I.D, $0.25 \mu \mathrm{m}$ film thicknes) according to the modified method of Yıldız-Turp \& Serdaroğlu (2008). The carrier gas is $\mathrm{H}_{2}$, which was used at a flow rate of $1 \mathrm{~mL} \mathrm{~min}^{-1}$. Sample was injected $(1 \mu \mathrm{L})$ with a split mode (ratio 50:1). Injector temperature and detector temperature were adjusted at $225{ }^{\circ} \mathrm{C}$ and $250{ }^{\circ} \mathrm{C}$, respectively. Column oven temperature increased from $100{ }^{\circ} \mathrm{C}$ (hold $4 \mathrm{~min}$ ) to $240{ }^{\circ} \mathrm{C}$ at a rate of $3{ }^{\circ} \mathrm{C} \mathrm{min}{ }^{-1}$, and kept at $240{ }^{\circ} \mathrm{C}$ for $15 \mathrm{~min}$. Fatty acids composition 
of samples was identified with retention times of individual fatty acid obtained from commercial standard (Restek, Food industry FAME mix-37 components, cat.\# 35077) and the defined each peak was expressed as a percentage of the total area of all peaks.

\subsubsection{Statistical analysis}

All assays were performed in triplicate. Data analyses were carried out using SPSS software v 20.0 and Duncan multiple range test at $\mathrm{P}<0.05$ probability level.

\section{Results and Discussion}

\subsection{Proximate composition of fig seeds}

The moisture contents of fig seeds were from 5.54 to $5.64 \%$ while the ash contents of them were $2.99 \%$ (Table 1). There were not found significant differences in the moisture and ash contents of fig seeds obtained from different fig varieties $(\mathrm{P}<0.05)$. Morton (1987) and Kim et al (1992) reported moisture content of the fresh figs as $77.5-88.70 \%$ and ash content of the fresh figs as $0.44-0.85 \%$. Compared to whole fig, the lower moisture contents in the fig seeds are expected due to the fact that the jelly-like flesh found in the whole figs is higher amount than the fig seeds. The reason why fig seeds have higher ash content is also that jelly-like meat is not found in fig seeds. The fact that fig seeds have low moisture and high ash contents is a very positive feature. Because, low moisture content increases the shelf life of product and high ash content also increases the possibility of existed more minerals having positive health effects in the structure of fig seeds.
The oil and protein contents of the fig seeds ranged from 23.06 to $23.67 \%$ and from 14.74 to 15.07, respectively (Table 1), these values are higher compared to data reported by Morton (1987) and Kim et al (1992). They reported the oil and protein contents of fresh figs as $0.14-0.31 \%$ and $0.70-1.3 \%$, respectively. This is evidence that the fig seeds contribute significantly to the protein and oil contents of the figs. Besides, it was determined that the fig seeds in Germencik location had the highest contents of oil and protein and the fig seeds in Nazilli location had the lowest contents of oil and protein $(\mathrm{P}<0.05)$. Generally, the presence of high amounts of oil and protein in fig seeds is an indication that they may be beneficial to health because they are rich in fatty acids and contain essential amino acids.

Fig seeds were found to be good sources of carbohydrate. The obtained results demonstrated that the carbohydrate contents of fig seeds were $52.62-53.66 \%$ (Table 1), which was significantly higher than the carbohydrate contents (17.1-20.3 g $100 \mathrm{~g}^{-1}$ fresh fig) of figs (Morton 1987; Guvenc et al 2009). The significant differences in carbohydrate contents of the analyzed samples determined $(\mathrm{P}<0.05)$. Although the fig seeds in Nazilli location had the highest amount of carbohydrate content, the fig seeds in Germencik location had the lowest amounts of carbohydrate contents.

\subsection{Mineral content of fig seeds}

The mineral levels of fig seeds were analyzed by UV-vis spectrophotometer (for only P analysis) and an atomic absorption spectrometer with a flame atomize. The performance characteristics of the HR-CSFAAS method were given in Table 2.

Table 1- Some chemical properties of fig (Ficus carica L.) seeds

\begin{tabular}{lccccc}
\hline Location & $\begin{array}{c}\text { Moisture content } \\
(\%) *\end{array}$ & $\begin{array}{c}\text { Ash content } \\
(\%) *\end{array}$ & $\begin{array}{c}\text { Oil content } \\
(\%)\end{array}$ & $\begin{array}{c}\text { Protein content } \\
(\%)\end{array}$ & $\begin{array}{c}\text { Carbohydrate content } \\
(\%)\end{array}$ \\
\hline Incirliova & $5.59 \pm 0.07$ & $2.99 \pm 0.01$ & $23.37 \pm 0.15 \mathrm{ab}$ & $14.92 \pm 0.12 \mathrm{ab}$ & $53.13 \pm 0.19 \mathrm{ab}$ \\
Germencik & $5.64 \pm 0.06$ & $2.99 \pm 0.01$ & $23.67 \pm 0.14 \mathrm{a}$ & $15.07 \pm 0.07 \mathrm{a}$ & $52.62 \pm 0.11 \mathrm{~b}$ \\
Nazilli & $5.54 \pm 0.04$ & $2.99 \pm 0.01$ & $23.06 \pm 0.10 \mathrm{~b}$ & $14.74 \pm 0.14 \mathrm{~b}$ & $53.66 \pm 0.21 \mathrm{a}$ \\
\hline
\end{tabular}

Data are expressed as mean \pm standard deviation in triplicate $(n=3)$. Different letters $(a, b, c, d$, and so on) in the same column show significant differences $(\mathrm{P}<0.05) .{ }^{*}$, no statistically significant differences $(\mathrm{P}>0.05)$ 
Table 2- Performance characteristics of the HR-CS-FAAS method

\begin{tabular}{lccccccc}
\hline Minerals & $\begin{array}{c}\text { LOD } \\
\left(m g L^{-1}\right)\end{array}$ & $\begin{array}{c}\text { LOQ } \\
\left(m g L^{-1}\right)\end{array}$ & $\begin{array}{c}R S D \\
(\%)\end{array}$ & $\begin{array}{c}\text { Calibration range } \\
\left(m g L^{-1}\right)\end{array}$ & $r$ & $\begin{array}{c}\text { Regression } \\
\text { equation }\end{array}$ & $\begin{array}{c}R \\
(\%)\end{array}$ \\
\hline $\mathrm{Mg}$ & 0.47 & 1.56 & 6.50 & $0.2-1.5$ & 0.9050 & $\mathrm{y}=0.1559549+0.7635861 \times$ & 98.50 \\
$\mathrm{Mn}$ & 0.09 & 0.31 & 2.50 & $0.2-1.5$ & 0.9961 & $\mathrm{y}=0.0085974+0.2259809 \times$ & 89.20 \\
$\mathrm{Zn}$ & 0.19 & 0.63 & 9.50 & $0.2-1.5$ & 0.9840 & $\mathrm{y}=0.0819164+0.2810132 \mathrm{x}$ & 96.80 \\
$\mathrm{Fe}$ & 0.13 & 0.43 & 6.80 & $0.5-3.8$ & 0.9970 & $\mathrm{y}=0.0094184+0.0671127 \mathrm{x}$ & 95.60 \\
$\mathrm{Ca}$ & 1.14 & 3.80 & 2.10 & $1.0-4.0$ & 0.9488 & $\mathrm{y}=0.0059524+0.0582419 \times$ & 87.40 \\
$\mathrm{Cu}$ & 0.31 & 1.05 & 0.80 & $0.5-4.0$ & 0.9561 & $\mathrm{y}=-0.0004395+0.3672192 \times$ & 94.00 \\
$\mathrm{Na}$ & 0.49 & 1.62 & 0.90 & $1.0-2.5$ & 0.9635 & $\mathrm{y}=0.3499030+0.4490676 \times$ & 98.80 \\
$\mathrm{~K}$ & 0.33 & 1.10 & 1.60 & $0.5-4.0$ & 0.9924 & $\mathrm{y}=0.0330507+0.2026023 \mathrm{x}$ & 94.50 \\
\hline
\end{tabular}

LOD, limit of detection; LOQ, limit of quantification; RSD, relative standard deviation; $r$, correlation coefficient; R, recovery in coffee samples

There was a significant difference $(\mathrm{P}<0.05)$ among samples in terms of mineral contents $(\mathrm{Mg}, \mathrm{Zn}$, $\mathrm{Fe}, \mathrm{Cu}, \mathrm{Na}, \mathrm{K}$ and $\mathrm{P}$ ) in fig seeds, except $\mathrm{Ca}$ and $\mathrm{Mn}$ (Table 3). The results statistically expressed that $\mathrm{Ca}$, $\mathrm{K}$ and $\mathrm{P}$ were the major minerals and $\mathrm{Cu}$ and $\mathrm{Mn}$ were also existed in trace amount in the analyzed samples $(\mathrm{P}<0.05)$. Aljane et al (2007) also found $\mathrm{K}$ and $\mathrm{Ca}$ as major minerals of fresh figs among the analyzed minerals ( $\mathrm{K}, \mathrm{Ca}, \mathrm{Mg}, \mathrm{Na}, \mathrm{Zn})$. In the study of Morton (1987), Ca, P, Fe, Na and K contents of fresh figs were investigated and major minerals of fresh figs were determined as $\mathrm{K}, \mathrm{Ca}$ and $\mathrm{P}$, which was similar to the results of this study. Mineral contents of fig seeds varied according to location characteristics; the fig seeds in Germencik location in terms of $\mathrm{Mg}, \mathrm{Zn}$ and $\mathrm{Cu}$ contents, the fig seeds in Nazilli location in terms of $\mathrm{Fe}, \mathrm{Na}, \mathrm{K}$ and $\mathrm{P}$ contents come forward $(\mathrm{P}<0.05)$. Minerals have key roles in the body to do necessary functions for healthy and lengthy life which is from building strong bones to transmitting nerve impulses (Gharibzahedi \& Jafari 2017). It is very important to determine the high-mineral foods because a balanced diet is aimed at providing almost all of the minerals needed for the body.

\subsection{Fatty acid composition of fig seeds}

In the oil of fig seeds, 14 fatty acids were identified (Table 4). Statistically significant differences were generally found between individual fatty acid contents of samples except heptadecanoic, $\alpha$-linolenic and lignoceric acids $(\mathrm{P}<0.05)$. The total saturated (SFA) and unsaturated fatty acid (MUFA and PUFA) percentages of fig seeds were in range $7.10-10.98 \%$ and $89.02-92.9 \%$, respectively. Similar to the study of Morton (1987), the major fatty acids of fig seeds were quantified as palmitic, oleic, linoleic and $\gamma$-linolenic acids. Arachidic acid was detected in smaller amount compare to other fatty

Table 3- Mineral contents (mg kg-1) of fig (Ficus carica L.) seeds

\begin{tabular}{llllllllll}
\hline Location & $M g$ & $M n *$ & $\mathrm{Zn}$ & $\mathrm{Fe}$ & $\mathrm{Ca}{ }^{*}$ & $\mathrm{Cu}$ & $\mathrm{Na}$ & $K$ & $P$ \\
\hline \multirow{3}{*}{ Incirliova } & $49.82 \pm$ & $7.90 \pm$ & $20.77 \pm$ & $52.31 \pm$ & $187.80 \pm$ & $5.29 \pm$ & $70.24 \pm$ & $169.78 \pm$ & $178.36 \pm$ \\
& $0.01 \mathrm{~b}$ & 0.19 & $0.23 \mathrm{~b}$ & $0.11 \mathrm{~b}$ & 3.71 & $0.03 \mathrm{ab}$ & $0.41 \mathrm{ab}$ & $0.07 \mathrm{~b}$ & $2.83 \mathrm{c}$ \\
Germencik & $53.66 \pm$ & $8.03 \pm$ & $22.56 \pm$ & $50.26 \pm$ & $185.67 \pm$ & $5.34 \pm$ & $69.45 \pm$ & $166.73 \pm$ & $181.78 \pm$ \\
& $0.01 \mathrm{a}$ & 0.10 & $0.43 \mathrm{a}$ & $0.15 \mathrm{c}$ & 3.54 & $0.01 \mathrm{a}$ & $0.28 \mathrm{~b}$ & $0.03 \mathrm{c}$ & $2.02 \mathrm{ab}$ \\
Nazilli & $46.36 \pm$ & $7.77 \pm$ & $18.26 \pm$ & $58.11 \pm$ & $190.42 \pm$ & $5.25 \pm$ & $70.82 \pm$ & $172.83 \pm$ & $186.21 \pm$ \\
\hline
\end{tabular}

Data are expressed as mean \pm standard deviation in triplicate $(n=3)$. Different letters $(a, b, c, d$, and so on) in the same column show significant differences $(\mathrm{P}<0.05)$. *, no statistically significant differences $(\mathrm{P}>0.05)$ 
acids. The concentrations of fatty acid components in the fig seeds was observed to be generally lower compared to those of the fresh whole figs analyzed by Guvenc et al (2009). It was noteworthy that the amounts of linoleic and $\gamma$-linolenic acids in the fig seeds were higher than linoleic and $\gamma$-linolenic acid contents $(1.46 \%)$ of the fresh figs. Also, the fig seeds in Germencik location came out as the sample with the highest PUFA and the lowest SFA.

It could have been said that the fig seed was a better source of linoleic and $\gamma$-linolenic acids. The fig seed oil is healthy oil which is rich in nutrients. It can be considered a commercial source, due to the fact that it contains w-3 ( $\alpha$-linolenic and cis$5,8,11,14,17$-eicosapentaenoic acid) and w-6 (linoleic acid) fatty acids. These fatty acids provide important contributions to human health and are known as essential fatty acids. It is also important that the amount of unsaturated fatty acids in fig seed oil is higher than that of saturated fatty acids.
As a result of this study, it was determined that the biochemical characteristics of fig seeds obtained from Sarilop fresh figs which are grown at different locations were different from each other. It is thought that this difference is caused by the difference of location (soil structure, irrigation etc.) where the figs are grown, although the fig seeds obtained from the same fig cultivar are examined. The fig seeds of the Germencik location were identified as sample having the highest fat, protein, some minerals $(\mathrm{Mg}$, $\mathrm{Zn}$ and $\mathrm{Cu}$ ) and PUFA contents in this study.

\section{Conclusions}

This is the first study to investigate the chemical properties and nutritional compositions of fig seeds. Fig is a fruit which considered as a functional food due to its unique physicochemical properties. The contribution rate of fig seeds to the nutritional characteristics of figs was determined for the first time by this study. It has been discovered that fig seeds

Table 4- Fatty acid compositions (\%) of fig (Ficus carica L.) seeds

\begin{tabular}{lllll}
\hline \multirow{2}{*}{ Fatty acids } & Common name & \multicolumn{2}{c}{ Location } & Nazilli \\
\cline { 3 - 5 } C16:0 & Palmitic acid & Incirliova & Germencik & $7.00 \pm 0.130 \mathrm{a}$ \\
C16:1 & Palmitoleic acid & $0.06 \pm 0.003 \mathrm{ab}$ & $0.06 \pm 0.003 \mathrm{a}$ & $0.05 \pm 0.001 \mathrm{~b}$ \\
C17:0 & Heptadecanoic acid* & $0.06 \pm 0.003$ & $0.06 \pm 0.002$ & $0.06 \pm 0.001$ \\
C18:0 & Stearic acid & $3.38 \pm 0.020 \mathrm{ab}$ & $3.73 \pm 0.180 \mathrm{a}$ & $2.97 \pm 0.330 \mathrm{~b}$ \\
C18:1n9c & Oleic acid & $16.82 \pm 0.070 \mathrm{~b}$ & $17.79 \pm 0.030 \mathrm{a}$ & $16.97 \pm 0.050 \mathrm{~b}$ \\
C18:2n6c & Linoleic acid & $32.81 \pm 0.750 \mathrm{~b}$ & $37.95 \pm 0.780 \mathrm{a}$ & $31.80 \pm 0.470 \mathrm{~b}$ \\
C20:0 & Arachidic acid & $0.02 \pm 0.003 \mathrm{ab}$ & $0.03 \pm 0.001 \mathrm{a}$ & $0.02 \pm 0.001 \mathrm{~b}$ \\
C18:3n6 & $\gamma$-linolenic acid & $37.87 \pm 0.160 \mathrm{~b}$ & $41.80 \pm 0.960 \mathrm{a}$ & $39.09 \pm 0.140 \mathrm{~b}$ \\
C20:1 & cis-11-Eicosenoic acid & $0.26 \pm 0.010 \mathrm{a}$ & $0.18 \pm 0.010 \mathrm{~b}$ & $0.23 \pm 0.030 \mathrm{ab}$ \\
C18:3n3 & $\alpha$-Linolenic acid* & $0.25 \pm 0.020$ & $0.30 \pm 0.030$ \\
C21:0 & Heneicosanoic acid & $0.30 \pm 0.020$ & $0.08 \pm 0.005 \mathrm{a}$ & $0.04 \pm 0.005 \mathrm{~b}$ \\
C20:3n6 & cis-8,11,14-Eicosatrienoic acid & $0.04 \pm 0.002 \mathrm{~b}$ & $0.04 \pm 0.005 \mathrm{~b}$ & $0.09 \pm 0.001 \mathrm{a}$ \\
C24:0 & Lignoceric acid* & $0.09 \pm 0.004 \mathrm{a}$ & $0.04 \pm 0.001$ & $0.03 \pm 0.001$ \\
C20:5n3 & cis-5,8,11,14,17-Eicosapentaenoic acid & $0.39 \pm 0.040 \mathrm{a}$ & $0.24 \pm 0.030 \mathrm{~b}$ & $0.11 \pm 0.010 \mathrm{c}$ \\
$\sum$ SFAs & & $10.98 \pm 0.260 \mathrm{a}$ & $7.10 \pm 0.140 \mathrm{~b}$ & $10.24 \pm 0.320 \mathrm{a}$ \\
$\sum$ MUFAs* & & $17.22 \pm 0.150$ & $17.05 \pm 0.300$ & $17.48 \pm 0.320$ \\
$\sum$ PUFAs & & $71.80 \pm 0.110 \mathrm{c}$ & $75.85 \pm 0.150 \mathrm{a}$ & $72.28 \pm 0.002 \mathrm{~b}$ \\
\hline
\end{tabular}

Data are expressed as mean \pm standard deviation in triplicate $(n=3)$. Different letters $(a, b, c, d$, and so on) in the same line show significant differences $(\mathrm{P}<0.05)$. *, no statistically significant differences $(\mathrm{P}>0.05)$. $\sum \mathrm{SFAs}$, total saturated fatty acids; $\sum$ MUFAs, total monounsaturated fatty acids; $\sum$ PUFAs, total polyunsaturated fatty acids 
contribute significantly to the chemical properties of figs by their rich nutritional content. It is obvious that fig seeds have significant support on the health benefits of figs. Considering the findings obtained in this study, the use of fig seeds as a pharmaceutical supplement can be possible and the commercialization of the fig seeds can come to the fore.

\section{Acknowledgements}

I wish to thank Prof. Dr. Yaşar HIŞIL for his technical support.

\section{References}

Aljane F, Toumi I \& Ferchichi A (2007). HPLC determination of sugars and atomic absorption analysis of mineral salts in fresh figs of Tunisian cultivars. African Journal of Biotechnology 6(5): 599-602

Amessis-Ouchemoukh N, Ouchemoukh S, Meziant N, Idiri Y, Hernanz D, Stinco C M, RodríguezPulido F J, Heredia F J, Madani K \& Luis J (2017). Bioactive metabolites involved in the antioxidant, anticancer and anticalpain activities of Ficus carica L., Ceratonia siliqua L. and Quercus ilex L. extracts. Industrial Crops and Products 95: 6-17

AOAC (1996). Phosphorus in Animal Feed and Pet Food (AOAC Methods 965.17-1966). Association of Official Analytical Chemist (AOAC), Arlington, VA

AOAC (2000). Official Methods of Analysis of AOAC International $\left(17^{\text {th }}\right.$ Ed.). Association of Official Analytical Chemists, Gaithersburg, MD

Badgujar S B, Patel V V, Bandivdekar A H \& Mahajan R T (2014). Traditional uses, phytochemistry and pharmacology of Ficus carica: a review. Pharmaceutical Biology 52(11): 1487-1503

Bucić-Kojić A, Planinić M, Tomas S, Jokić S, Mujić I, Bilić M \& Velić D (2011). Effect of extraction conditions on the extractability of phenolic compounds from lyophilised fig fruits (Ficus carica L.). Polish Journal of Food and Nutrition Sciences 61(3): 195-199

Çalişkan O, Mavi K \& Polat A (2012). Influences of presowing treatments on the germination and emergence of fig seeds (Ficus carica L.). Acta Scientiarum-Agronomy 34(3): 293-297

Engin B, Aydaş C \& Polat M (2011). Detection of gamma irradiated fig seeds by analysing electron spin resonance. Food Chemistry 126(4): 1877-1882
Gharibzahedi S M T \& Jafari S M (2017). The importance of minerals in human nutrition: bioavailability, food fortification, processing effects and nanoencapsulation. Trends in Food Science and Technology 62: 119-132

Guvenc M, Tuzcu M \& Yilmaz O (2009). Analysis of fatty acid and some lipophilic vitamins found in the fruits of the Ficus carica variety picked from the Adiyaman District. Research Journal of Biological Sciences 4(3): 320-323

Kim S S, Lee C H, Oh S L \& Chung D H (1992). Chemical components in two cultivars of Korean figs (Ficus carica L.). The Korean Society for Applied Biological Chemisty 35(1): 51-54

Lansky E P, Paavilainen H M, Pawlus A D \& Newman R A (2008). Ficus spp. (fig): ethnobotany and potential as anticancer and anti-inflammatory agents. Journal of Ethnopharmacology 119(2): 195-213

López A, García P \& Garrido A (2008). Multivariate characterization of table olives according to their mineral nutrient composition. Food Chemistry 106(1): 369-378

Mawa S, Husain K \& Jantan I (2013). Ficus carica L. (Moraceae): phytochemistry, traditional uses and biological activities. Evidence-Based Complementary and Alternative Medicine pp. 1-8

Mehta S, Soni N, Satpathy G \& Gupta R K (2014). Evaluation of nutritional, phytochemical, antioxidant and antibacterial activity of dried plum (Prunus domestica). Journal of Pharmacognosy and Phytochemistry 3(2): 158-165

Morton J F (1987). Fruits of Warm Climates. Echo Point Books \& Media, Miami, FL, 505 pp

Nakilcioğlu E \& Hışıl Y (2013). Research on the phenolic compounds in Sarilop (Ficus carica L.) fig variety. Gida 38(5): 267-274

Oliveira A P, Silva L R, Andrade P B, Valentão P, Silva B M, Pereira J A \& Guedes de Pinho P (2010). Determination of low molecular weight volatiles in Ficus carica using HS-SPME and GC/FID. Food Chemistry 121(4): 1289-1295

Paquot C \& Hautfenne A (1987). International Union of Pure and Applied Chemistry (IUPAC), Standard Method for the Analysis of Oils, Fats and Derivatives ( $7^{\text {th }}$ Ed.). Blackwell Scientific Publications. Blackwell Scientific Publications, London

Yildiz-Turp G \& Serdaroğlu M (2008). Effect of replacing beef fat with hazelnut oil on quality characteristics of sucuk - a Turkish fermented sausage. Meat Science 78(4): 447-454 